\title{
Effect of Problem Based Learning (PBL) Learning Strategies and Student Learning Styles on PKn Learning Outcomes of Grade V Students of Elementary School Experimental District of Kota Medan
}

\author{
Ramiyah $^{1}$, Reh Bungana Beru Perangin Angin ${ }^{2}$, Yusnadi ${ }^{2}$ \\ ${ }^{1}$ Master Student in State University of Medan, Indonesia \\ ${ }^{2}$ Lecturer in State University of Medan, Indonesia \\ Syahrunnisa20@gmail.com
}

\section{Abstract}

The problem in this study is the low learning achievement of Pancasila and Citizenship Education. The purpose of this study was to determine the effect of learning styles on the Learning Outcomes of Pancasila and Citizenship Education. The type of research used is a $2 \times 2$ factorial design study. The population of this study amounted to 60 students and the sample was taken as a whole from the total population of 60 people consisting of 30 from class Va and 30 from class Vb Elementary School Experiment in Medan. Data collection techniques using questionnaires (questionnaires) and tests. Data analysis techniques used product moment correlation and Statistical Product and Service Solutions (SPSS) programs. The results obtained indicate that the value of students who have a visual learning style has a difference with students who have auditory learning styles with a sig value of 0.000 and a mean difference of 4.5756. Between students who have a visual learning style, have a significant difference with students who have kinesthetic learning styles, with a sig value of 0.002 and a mean difference of 4.4940. Between students who have auditory learning styles did not have a significant difference with students who have kinesthetic learning styles, with a sig value of 0.998 and a mean difference of only 0.815 . The results showed that there was a significant effect between learning styles on the learning outcomes of Pancasila and Citizenship Education in the fifth grade students of SD Negeri Experiment City Medan

Keywords learning outcomes; student learning style; Pancasila and citizenship education

\section{Introduction}

Education is an obligation of every human being that must be pursued to hold responsibilities and try to produce progress in knowledge and experience for the lives of every individual. Indonesia is a developing country that also prioritizes and tries to develop all aspects of the education world (Astuti, 2019). Education is now a requirement for every human being. Indonesia as a constitutional state regulates education Undang Undang No. 20 Tahun 2003 concerning the National Education System article 1 paragraph 1 which reads: Education is a conscious and planned effort to create an atmosphere of learning and learning process so that students actively develop their potential to have spiritual strength, self-control, personality, intelligence, noble character, and the skills needed by themselves, society, nation and state.

Siswoyo stated that there are three central components in the educational effort, namely: students, educators, and educational goals that lead to educational interactions in 
them. Student components include: number of students, level of development, trait, level of readiness, interest, motivation, ideals. Educator components include, age of education, level of education, quality of experience, direct and indirect attendance, abilities, interests, commitment. The general purpose of education is contained in Article 3 of the Law on the National Education System which reads: National education functions to develop and shape the dignified character and civilization of the nation in the context of developing the intellectual life of the nation, aiming at developing the potential of learners to become human beings who believe in and fear God Almighty, have noble, healthy, knowledgeable, capable, creative, independent, and become democratic and responsible citizens.

In achieving the learning outcomes of Pkn, several supporting factors are needed including the learning strategy. Learning strategies used by teachers in the learning process become one of the determining factors in achieving learning outcomes. A teacher must have the ability to design a learning strategy in accordance with certain objectives to be achieved. A good learning strategy is a learning strategy that not only requires students to memorize theories but also how students are able to understand the concepts that gave rise to the theory. In other words, this strategy must prioritize student activity, let students find the concept of the material itself, this learning strategy is called a Problem Based Learning (PBL) learning strategy. PBL is a learning model that uses significant innovations in education because in PBL students' thinking abilities are truly optimized through systematic group or team work processes, so students can empower, hone, test, and develop their thinking abilities continuously (Rusman , 2011: 230).

One of the goals of Indonesia's national education is the development of the potential of independent students. Ambarita (2006: 90) states that independence will determine the attitude of a student which is shown by behavior related to self-management, self-direction, and self-control (personal control). In addition to the purpose of education to create the potential for independent students, the world of education must also prioritize the learning outcomes. Learning outcomes are always a major concern in the learning process. Learning outcomes are the results obtained by students after following the learning process that is indicated through the value or number of the results of evaluations conducted. In other words learning outcomes can be used as benchmarks in determining the competency of a lesson.

Seeing this condition, the teacher is expected to be able to find a strategy that not only requires students to memorize formulas or theories but rather to the understanding of students themselves in the discussion of material in Civics. The teacher must design a strategy where students are required to play an active role in the discovery of theoretical concepts and learning materials, because basically our brains are designed to be able to remember longer a matter if we take part directly in it. Self-solved problems, which are found alone without special assistance, give superior results, which are used or transferred in other situations. Therefore for education it is very important to encourage children to find solutions to problems with their own thoughts. For this reason, the Problem Based Learning (PBL) learning strategy is proposed to be the solution to the problem above.

\section{Research Methods}

The study was conducted at Medan City Experiment Elementary School. When the study was conducted in the odd semester of the 2017/2018 learning year. 
Table 1. Research Methods

\begin{tabular}{|c|c|c|c|c|c|c|c|c|c|c|c|c|c|}
\hline \multirow[t]{2}{*}{ No } & \multirow[t]{2}{*}{ Activities } & \multicolumn{4}{|c|}{ January } & \multicolumn{4}{|c|}{ February } & \multicolumn{4}{|c|}{ March } \\
\hline & & 1 & 2 & 3 & 4 & 1 & 2 & 3 & 4 & 1 & 2 & 3 & 4 \\
\hline 1. & $\begin{array}{l}\text { Approval of the } \\
\text { proposal }\end{array}$ & & & & & & & & & & & & \\
\hline 2. & Mail handling & & & & & & & & & & & & \\
\hline 3. & $\begin{array}{l}\text { Designing } \\
\text { instruments }\end{array}$ & & & & & & & & & & & & \\
\hline 4. & $\begin{array}{l}\text { Pretest, study and } \\
\text { posttest }\end{array}$ & & & & & & & & & & & & \\
\hline 5. & Data collection & & & & & & & & & & & & \\
\hline 6. & $\begin{array}{l}\text { Processing and data } \\
\text { analysis }\end{array}$ & & & & & & & & & & & & \\
\hline 7. & Report writing & & & & & & & & & & & & \\
\hline
\end{tabular}

The population is the whole object to be studied. In other words the whole object becomes the source of all the data needed in a study. In this study, the population was all fifth grade students of SD Negeri Medan City Experiment, Academic Year 2017/2018. The total of 60 people and divided into classes Va - Vb. Table Number of Grade V Students in Medan Elementary School.

Research Samples the sample is part or representative of the population studied. Sampling is done by total sampling technique, as stated by Arikunto (2009: 112) that "If the subject is less than 100 people better taken all so that research is population research".

Table 2. Number of Grade V Students in Medan Elementary School, Medan

\begin{tabular}{|c|c|}
\hline KELAS & JUMLAH \\
\hline V-A & 30 orang \\
\hline V-B & 30 orang \\
\hline
\end{tabular}

Table 3. Research Sample

\begin{tabular}{|c|c|}
\hline Class V-A & Control Class \\
\hline Class V-B & Experiment Class \\
\hline
\end{tabular}

\subsection{Data collection technique}

\section{a. Observation}

Observation is an activity in the context of collecting data related to research problems through the process of direct observation in the field. In this case the researchers made direct observations to Medan City Experiment Elementary School, seeing how the teaching and learning process took place in the classroom.

\section{b. Documentation}

Researchers collected documents in the form of learning outcomes that relate to the fifth grade of SD Negeri Experiment Medan City taken from a list of collected values obtained from the teacher. 


\section{c. Interview}

Interview is a conversation with a specific purpose conducted by two parties, namely interviewer (interviewer) and interviewee (interviewed). In this case the researcher conducted interviews with Civics subject teachers as well as with fifth grade students of Medan City Experiment Elementary School.

\section{d. Test}

The test used is a test in the form of PKn student learning outcomes in multiple forms as many as 10 multiple choice questions cited from the fifth grade PKn package book which are considered valid and reliable, as a test not tested. The data collection tool used is to provide a posttest conducted after the treatment process is completed to find out how much influence the PBL learning strategy has on the learning outcomes of class V students

\section{e. Questionnaire}

To determine student learning styles, questionnaires are used. Questionnaire is a list of questions or statements about certain topics given to subjects, either individually or in groups to get certain information, such as preferences, beliefs, interests, and behavior. The questionnaire given to respondents was about how students learn at home.

To achieve these objectives, data is needed, namely data on how students learn at home in the form of categories and weights.

1) The measuring instrument used was a questionnaire and was arranged using four answer choices.

2) The scale in this study is guided by the Likert scale which measures a person's attitudes, opinions and perceptions about social phenomena by providing 4 alternative answers.

3) Determination of the value of the choice of answers arranged as follows:

A. Often $=$ value 4

B. Rarely $=$ value 3

C. Occasional $=$ value 2

D. Never $=$ value 1

\section{Result and Discussion}

Based on the results of the hypothesis test shows that there are differences in student learning outcomes that have Auditory, visual and kinesthetic learning styles, it is shown by the results of research showing that the significance value is 0,000 which is lower than the critical threshold of 0.05 . Learning style is a combination of how a person absorbs and then organizes and processes information. Learning style is not only an aspect when dealing with information, seeing, listening, writing and saying but also aspects of secondary, analytic, global information processing or the left brain and right brain. Another aspect is when responding to something about the learning environment (absorbed abstractly and concretely).

\section{a. First Hypothesis}

To answer the first hypothesis, it can be concluded that the significance value is 0.000 , which is lower than the critical value of 0.05 . So it was concluded there were differences in PKN learning outcomes between students taught with PBL with conventional. The first hypothesis is accepted. 


\section{b. Second Hypothesis}

To answer the second hypothesis, the learning style column is viewed. The significance value is 0,000 which is lower than the critical threshold of 0.05 . Means there are differences in learning outcomes between students who have student learning styles. Be it visual, auditory and kinesthetic. Then the second hypothesis is accepted.

\section{c. Third Hypothesis}

To answer the third hypothesis, namely whether there is an interaction between learning strategies with students' learning styles, answers can be seen in the Student Learning Styles Learning Strategies column. It can be seen that the significance value is 0.005 , lower than 0.05. Means there is an interaction between learning strategies with student learning styles. Then the third hypothesis is accepted

There are three types of learning styles that will be discussed in this research namely visual (tend to learn through what they see), auditory (learning through what they hear) and kinesthetic (learning through motion and touch). As instructors, teachers or lecturers not only carry out the process of transforming knowledge to students, but more than that a teacher must act as a motivator, inspirator, facilitator and mediator in the learning process of students. Therefore, a teacher or lecturer does not only conduct the teaching process but is also required to carry out the learning process. The effectiveness of learning refers to the achievement of learning objectives which is very important in the learning process because models, approaches, strategies, methods and learning techniques determine the success or failure of achieving goals. To determine effective and efficient learning methods and techniques, guidelines are needed that are sourced from various factors, namely learning objectives, students, and supporting facilities / infrastructure. Hasrul $(2009 ; 1)$

Based on the results of the second hypothesis test shows that there are differences in student learning outcomes that have Auditory, visual and kinesthetic learning styles, it is shown by the results of research that show that the significance value is 0,000 which is lower than the critical threshold of 0.05 . Learning style is a combination of how a person absorbs and then organizes and processes information. Learning style is not only an aspect when dealing with information, seeing, listening, writing and saying but also aspects of secondary, analytic, global information processing or the left brain and right brain.

The effectiveness of learning refers to the achievement of learning objectives which is very important in the learning process because models, approaches, strategies, methods and learning techniques determine the success or failure of achieving goals. To determine effective and efficient learning methods and techniques, guidelines are needed that are sourced from various factors, namely learning objectives, students, and supporting facilities / infrastructure. Hasrul $(2009 ; 1)$ A person's ability to understand and absorb lessons is certainly different in level. Some are fast, moderate, and some are very slow (Hamzah B. Uno, 2008: 180). Therefore, they often have to take different ways to understand the same information or lessons. There are students who prefer to write things that have been delivered by the teacher when the learning process takes place.

There are also students who prefer to listen to the material delivered by the teacher, and there are also students who prefer to practice directly. From the various activities carried out by students during the learning process, it will create a way of learning that becomes a student's habit in daily life. The way students learn is often referred to as learning styles or student learning modalities. Learning style is a combination of how it absorbs, and then 
organizes and processes information (DePorter \& Hernacki, 2002: 110). Sugihartono (2007: 53) explains that learning styles are a collection of personal characteristics that make learning effective for some people and ineffective for others. Keefe in Sugihartono (2007: 53) states that learning styles are related to the way children learn, as well as the preferred way of learning. Nasution, (2003: 94) said learning style is a consistent way that is done by a student in capturing stimulus or information, how to remember, think, and solve problems. Students in general will find it difficult to process information in a way that feels uncomfortable to them.

A person's ability to understand and absorb lessons is certainly different in level. Some are fast, moderate, and some are very slow (Hamzah B. Uno, 2008: 180). Therefore, they often have to take different ways to understand the same information or lessons. There are students who prefer to write things that have been delivered by the teacher when the learning process takes place. There are also students who prefer to listen to the material delivered by the teacher, and there are also students who prefer to practice directly.

From the various activities carried out by students during the learning process, it will create a way of learning that becomes a student's habit in daily life. The way students learn is often referred to as learning styles or student learning modalities. Learning style is a combination of how it absorbs, and then organizes and processes information (DePorter \& Hernacki, 2002: 110). Sugihartono (2007: 53) explains that learning styles are a collection of personal characteristics that make learning effective for some people and ineffective for others. Keefe in Sugihartono (2007: 53) states that learning styles are related to the way children learn, as well as the preferred way of learning. Nasution, (2003: 94) said learning style is a consistent way that is done by a student in capturing stimulus or information, how to remember, think, and solve problems. Students in general will find it difficult to process information in a way that feels uncomfortable to them.

From some of the definitions of learning styles above, it can be concluded that learning style is the way a person is used in the learning process which includes how to capture, organize, and process the information received so that learning becomes effective. So it can be concluded that motivation influences student learning outcomes.

\section{Conclusion}

There are differences in student learning outcomes between students who are taught with Problem Based Learning strategies and Students who are taught with Conventional Learning Strategies. This can be seen from the research data which shows there are differences in Civics learning outcomes between students taught with PBL and conventional. It can be seen that the research data shows that the significance value is 0,000 which is lower than the critical value of 0.05 . The results obtained indicate that the value of students who have a visual learning style, has a difference with students who have an auditory learning style with a sig value of 0,000 and a mean difference of 4.5756. So there are differences in PKN learning outcomes between students taught with PBL with conventional learning, this is evidenced by students who use learning strategies Problem Based Learning is more able to solve problems and more courageous in expressing opinions compared to students who use conventional learning strategies

There are differences in student learning outcomes that have student learning styles, both visual learning styles, auditory learning styles and kinesthetic learning styles. This can be seen from the research data which shows that the significance value is 0.000 which is 
lower than the critical threshold of 0.05 which shows that learning outcomes using visual learning styles are higher compared to auditory learning styles and with kinesthetic learning styles. students who have a visual learning style, have a significant difference with students who have a kinesthetic learning style, with a sig value of 0.002 and a mean difference of 4.4940 students who have an auditory learning style apparently do not have significant differences with students who have a kinesthetic learning style, with a sig value of 0.998 and a mean difference of only 0.815

There is a positive interaction between learning strategies and student learning styles. This can be seen from the research data which shows that the significance value is 0.005 , lower than 0.05. Thus, it can be concluded that the Problem Based Learning strategy and student learning styles influence the student learning outcomes in Civics V subjects in fifth grade SD Negeri Medan City.

\section{References}

Alben Ambarita. 2006. Manajemen Pembelajaran. Jakarta: Departemen Pendidikan Nasional Arends, I Richard. 2009. Learning To Teach. New York: McGraw-Hill Arikunto, Suharsimi. 2009. Dasar - Dasar Evaluasi Pendidikan. Jakarta: Bumi Aksara.

Astuti, R. W, et al. (2019). Character Education Values in Animation Movie of Nussa and Rarra. Budapest International Research and Critics Institute (BIRCI-Journal), 2(4); 215-219.

Daryanto. 2014. Pendekatan Pembelajaran Saintifik Kurikulum 2013. Yogyakarta: Gava Media.

DePorter, Bobbi \& Mike Hernacki. 2002. Quantum Learning: Membiasakan Belajar Nyaman dan Menyenangkan. Bandung: Kaifa

Djamarah, Bahri Syaiful. 2002. Rahasia Sukses Belajar. Jakarta: Rineka Cipta

Siswoyo, dkk. 2011. Ilmu Pendidikan. Yogyakarta: UNY Press

Hamzah B. Uno. 2008. Orientasi Baru Dalam Psikologi Pembelajaran. Jakarta: Bumi Aksara

Kaelan, 2007. Pendidikan Kewarganegaraan. Yogyakarta: Universitas Gajah Mada.

Mansoer, 2005. Pendidikan Kewarganegaraan. Yogyakarta: Pustaka Pelajar.

Muslichah Asy'ari. 2006. Penerapan Pendekatan Sains-teknologi-Masyarakat dalam Pembelajaran Sains di Sekolah Dasar. Yogyakarta: Universitas Sanata Dharma Yogyakarta

M. Taufiq Amir. 2009. Inovasi Pendidikan Melalui Problem Based Learning.Jakarta: Kencana Prenada Media Group.

Rusman. 2011. Model-model Pembelajaran Mengembangkan Profesionalisme Guru. Jakarta: Rajawali Press

Rusmono. 2012. Strategi Pembelajaran dengan Problem based Learning Itu Perlu untuk meningkatkan profesionalitas Guru. Bogor: Ghalia Indonesia.

Sagala, Syaiful. 2012. Konsep dan Makna Pembelajaran. Bandung: Alfabeta. 